\title{
Country-wide distribution of bluetongue virus with expanding host spectrum and evidence of vector competence in Hungary
}

\author{
M. DOMÁN ${ }^{1 \#}$, S. MARTON ${ }^{1 \# *}$, P. MALIK ${ }^{2}, K^{2}$ BÁNYAI ${ }^{1}$, Á. HORNYÁK ${ }^{2}$
}

${ }^{1}$ Institute for Veterinary Medical Research, Centre for Agricultural Research, Hungarian Academy of Sciences, , H-1581 Budapest, P.O. Box 18, Budapest, Hungary; ${ }^{2}$ Veterinary Diagnostic Directorate, National Food Chain Safety Office, Budapest, Hungary

Received May 21, 2018; revised September 6, 2018; accepted May 9, 2019

\begin{abstract}
Summary. - Following the introduction of bluetongue virus type 4 (BTV-4) in 2014, country-wide monitoring of bluetongue (BT) disease was performed to see whether the virus has become enzootic in Hungary. To analyse the epizootiology of BT, over 110,000 samples collected from domestic and wild ruminants were screened for the presence of BTV RNA and virus-specific antibodies using real-time RT-PCR assay and commercial ELISA kit, respectively. During laboratory analysis, specimens collected from $333(0.8 \%)$ cattle, 79 (2.2\%) sheep, $4(0.9 \%)$ goats, and $1(2.3 \%)$ mouflon were found to be positive by viral RNA-detection assay. In addition, antibody to BTV was detected in 5.5\% (3158/57,250) of cattle, 10.1\% (517/5120) of sheep, 40\% $(116 / 290)$ of goat, and $5.6 \%$ (16/284) of buffalo origin samples. The majority of positive samples originated from south-western counties; however, 18 out of 19 counties reported cases or antibody prevalence in the examined animals. Genome sequencing of a representative BTV-4 strain from 2015 was also performed. When comparing this strain with the isolate BTV4-HUN2014 detected only a year earlier in Hungary, mutations at 14 sites were identified within the amplified and sequenced genome. Our findings reinforce the need for continued surveillance of BT disease in Hungary.
\end{abstract}

Keywords: reoviridae; orbivirus; cattle; sheep; goat; biting midge

\section{Introduction}

Bluetongue virus (BTV) is the causative agent of a vectorborne disease of ruminants principally transmitted by biting midges (Culicoides spp.). Bluetongue is a hemorrhagic disease with high mortality rates in sheep, while cattle and other domestic or wild ruminant species may act as reservoirs without clinical signs (Saegerman et al., 2008; Casaubon et al., 2013). The BTV genome comprises 10 double-stranded RNA segments that encode different viral and non-structural proteins (VP1-7; NS1-3). Based on VP2, the major capsid protein that is responsible for antigenic variability, 28 distinct

*Corresponding author. E-mail: marton.szilvia@agrar.mta.hu; phone: +36-1-467-4060. " These authors have contributed equally to this work.

Abbreviations: $\mathrm{BT}=$ bluetongue; $\mathrm{BTV}=$ bluetongue virus; $\mathrm{BTV}-4$ $=\mathrm{BTV}$ serotype $4 \mathrm{Ct}=$ cycle threshold
BTV serotypes and 3 putative serotypes have been reported so far (Maan et al., 2011; Zientara et al., 2014; Sun et al., 2016; Savini et al., 2017).

Previously, BTV infections were restricted to regions between latitudes of $40-50^{\circ} \mathrm{N}$ and $35^{\circ} \mathrm{S}$, but since $2006-2007$ BTV has spread to northern parts of the world mainly due to climate change and extended vector competence (Vangeel et al., 2012). Appearance of the virus in Europe is associated with at least two unrelated incursion routes, such as the eastern and the western epidemiological system. Over the past two decades outbreaks caused by serotypes $1,2,4,6,8,9$, 11,14 , and 16 have occurred in several European countries (Breard et al., 2007; Orłowska et al., 2016). Since the first incursion to Europe (Greek Islands; late 1970s), serotype 4 BTV (BTV-4) strains have emerged in Bulgaria and Turkey. In addition, during the $21^{\text {st }}$ century, outbreaks were also recorded in Italy, France, Spain, Portugal, the United Kingdom, Denmark, Norway, and Sweden (Breard et al., 2007; Saegerman et al., 2008; Durand et al., 2010; Lorusso et al., 
2013). Phylogeographic analyses have identified two discrete strains of BTV-4 in Europe, a finding that is consistent with their geographical origin (Katsoulos et al., 2016).

In 2007 serological testing has identified a BT-seropositive cattle in Hungary; this animal was imported from another European country (Malik et al., 2008). Thereafter, countrywide monitoring was initiated to identify BT cases. As BTV has not been enzootic in Hungary, the majority of the ruminant population was immunologically naïve to the virus, enabling rapid spread of BTV under favorable ecological and epidemiological conditions. During 2014 increasing number of BTV cases was recorded, especially in the south-eastern counties of Hungary, which was linked to an ongoing outbreak reported in Greece and Bulgaria. Sequence analyses classified the Hungarian BTV strain to serotype 4 (Hornyák et al., 2015). In September 2015, a new BTV outbreak was reported, therefore the aim of our study was to analyse the epizootiology of BT in Hungary during 2015. In this period the surveillance was extended to examine the possible role of wild ruminants in the maintenance of BTV and the role of biting midges for vector competence.

\section{Materials and Methods}

Samples. Between January and December 2015 a total of 47,273 and 63,146 samples were processed at the National Reference Laboratory of Veterinary Diagnosis Directorate of National Food Chain Safety Office for viral nucleic acid and virus-specific antibody detection, respectively. Anticoagulant-treated and non-treated blood samples collected from all over the country were collected from cattle, sheep, goat, buffalo and several wild ruminant species (e.g. roe deer, fallow deer, red deer, mouflon). Biting midges were collected by light traps in the proximity of the stalls. Midges were transported in $70 \%$ ethanol to the National Reference Laboratory to identify them and carry out PCR tests.

Real-time RT-PCR. BTV genomic RNA was identified by real-time RT-PCR method. In brief, BTV RNA was isolated with MagNa Pure LC Total Nucleic Acid Isolation kit (Roche, Germany). After RNA extraction, specific primers to Segment-10 (NS3) were used in a quantitative one-step RT-PCR (qRT-PCR) assay (Hofmann et al., 2008). The reaction mixture was prepared in a final volume of $15 \mu \mathrm{l}$ that contained $2 \mu \mathrm{l}$ RNA, $3 \mu \mathrm{l} 5 \mathrm{x}$ Qiagen OneStep RT-PCR buffer, $0.8 \mu \mathrm{MgCl}_{2}, 0.6 \mu \mathrm{l} \mathrm{dNT}, 1 \mu \mathrm{l}$ forward primer (5'-TGGAYAAAGCGATGTCAAA-3'), $1 \mu$ reverse primer (5'-ACATCATCACGAAACGCTTC-3'), $0.6 \mu l$ probe (5'FAMARGCTGCATTCGCATCGTACGC-3' BHQ1), $0.6 \mu$ l Qiagen enzyme mix and $5.4 \mu \mathrm{l}$ distilled water. The thermal profile of qRT-PCR consisted of $55^{\circ} \mathrm{C}$ for $30 \mathrm{~min}$ (reverse transcription), $95^{\circ} \mathrm{C}$ for $15 \mathrm{~min}$ (denaturation), followed by 45 cycles of $95^{\circ} \mathrm{C}$ for $20 \mathrm{~s}, 50^{\circ} \mathrm{C}$ for $30 \mathrm{~s}$ and $72^{\circ} \mathrm{C}$ for $30 \mathrm{~s}$. Fluorescence was measured at the end of $50^{\circ} \mathrm{C}$ annealing step. Cycle threshold $(\mathrm{Ct})$ values were determined from the point at which the sample fluorescence signal crossed a threshold value. Samples with Ct values greater than 40 were considered as negative.

Antibody detection. BTV specific monoclonal antibody detection was carried out with INgezim BTV Compac 2.0 (Ingenasa, Madrid, Spain) ELISA test, which contains recombinant BTV VP7 protein as target antigen. The test was performed according to the manufacturer's instructions. The optical density (OD) of wells was measured at $450 \mathrm{~nm}$. Samples were considered positive if their OD value was equal to or lower than the positive cut off and negative if their OD value was equal to or higher than the negative cut off. The positive results were confirmed by INgezim BTV DR immunoenzymatic assay (Ingenasa, Madrid, Spain).

Virus genome analysis. Two Hungarian BTV strains isolated from cattle during 2015 were selected for sequencing. Direct sequencing was carried out using published oligonucleotide primers (Eschbaumer et al., 2011). The obtained partial sequence of the VP2 coding gene (540 bp) was used for phylogenetic analysis. BLAST analysis was carried out to compare nucleotide sequence of Hungarian BTV strains to other BTV strains with available sequence data. Multiple sequence alignments were generated by the Translator $\mathrm{X}$ online platform (http://translatorx.co.uk/), then phylogenetic analysis was performed with the MEGA 6 software (https://www. megasoftware.net/) to determine genetic relatedness among BTV strains. The best-fit substitution model with the lowest Bayesian information criterion value for each data set was used to construct maximum-likelihood tree. The tree topologies were validated by bootstrap analysis (1000 replicates). In order to identify possible changes within the genome, one BTV-4 isolate from 2015 was selected for whole genome sequencing. In brief, random-primed RT-PCR assay was used for the amplification of the whole genome that was followed by next generation sequencing using the Ion Torrent platform as described in detail elsewhere (Bányai et al., 2014).

\section{Results}

Among the 47,273 samples tested by qRT-PCR, 424 $(0.9 \%)$ gave positive results. The $\mathrm{Ct}$ values ranged from 15.98 to 39.98 (mean Ct value, 34.3; median Ct value, 34.9). Most samples were collected from cattle $(42,841)$, of which $333(0.8 \%)$ were positive for BTV. The majority of positive animals $(n=254 ; 76.3 \%)$ originated from the south-western regions (i.e. Baranya, Somogy, Tolna counties). Concerning ovine specimens, out of 3608 samples 79 (2.2\%) were found to be positive, however, all of these were sampled from two counties, Baranya $(n=21)$ and Somogy $(n=58)$. All four BTV positive goat samples $(0.9 \%)$ were collected from Baranya county. None of the 43 buffalo blood samples tested for BTV RNA gave positive results. Three positive cases (2.5\%) were detected out of 119 samples from other ruminants, which were also involved in the study. One of these positives was collected from a mouflon (2.3\%) (Table 1). The large number of positive samples in the south-western 
Table 1. County-based detection of BTV RNA and antibody in Hungary, 2015

\begin{tabular}{|c|c|c|c|c|c|c|c|c|c|c|c|}
\hline & \multicolumn{11}{|c|}{ Number of positive samples } \\
\hline & \multicolumn{2}{|c|}{ Cattle } & \multicolumn{2}{|c|}{ Sheep } & \multicolumn{2}{|c|}{ Goat } & \multicolumn{2}{|c|}{ Buffalo } & \multirow{2}{*}{$\begin{array}{c}\begin{array}{c}\text { Biting } \\
\text { midge }\end{array} \\
\text { RNA } \\
\end{array}$} & \multicolumn{2}{|c|}{ Other animal } \\
\hline & $\mathrm{Ab}$ & RNA & $\mathbf{A b}$ & RNA & $\mathbf{A b}$ & RNA & $\mathrm{Ab}$ & RNA & & $\mathbf{A b}$ & RNA \\
\hline Baranya & 454 & 48 & 132 & 21 & 62 & 4 & 0 & 0 & 0 & 0 & 0 \\
\hline Borsod-Abaúj-Zemplén & 83 & 6 & 1 & 0 & 0 & 0 & 0 & 0 & 1 & 0 & 0 \\
\hline Bács-Kiskun & 464 & 7 & 2 & 0 & 1 & 0 & 4 & 0 & 0 & 0 & 0 \\
\hline Békés & 150 & 0 & 0 & 0 & 0 & 0 & 0 & 0 & 0 & 0 & 0 \\
\hline Csongrád & 113 & 7 & 0 & 0 & 0 & 0 & 0 & 0 & 1 & 0 & 0 \\
\hline Fejér & 226 & 8 & 0 & 0 & 0 & 0 & 0 & 0 & 0 & 0 & 0 \\
\hline Győr-Moson-Sopron & 13 & 1 & 2 & 0 & 0 & 0 & 0 & 0 & 0 & 0 & 0 \\
\hline Hajdú-Bihar & 68 & 4 & 1 & 0 & 0 & 0 & 1 & 0 & 0 & 0 & 0 \\
\hline Heves & 26 & 0 & 1 & 0 & 0 & 0 & 0 & 0 & 0 & 0 & 0 \\
\hline Jász-Nagykun-Szolnok & 36 & 1 & 4 & 0 & 0 & 0 & 0 & 0 & 1 & 0 & 0 \\
\hline Komárom-Esztergom & 0 & 0 & 0 & 0 & 0 & 0 & 0 & 0 & 0 & 0 & 0 \\
\hline Nógrád & 220 & 34 & 0 & 0 & 0 & 0 & 0 & 0 & 0 & 0 & 0 \\
\hline Pest & 284 & 7 & 5 & 0 & 0 & 0 & 0 & 0 & 1 & 0 & $3^{*}$ \\
\hline Somogy & 416 & 137 & 352 & 58 & 53 & 0 & 6 & 0 & 0 & 0 & 0 \\
\hline Szabolcs-Szatmár-Bereg & 122 & 3 & 0 & 0 & 0 & 0 & 0 & 0 & 0 & 0 & 0 \\
\hline Tolna & 405 & 69 & 17 & 0 & 0 & 0 & 0 & 0 & 0 & 0 & 0 \\
\hline Vas & 10 & 0 & 0 & 0 & 0 & 0 & 0 & 0 & 0 & 0 & 0 \\
\hline Veszprém & 46 & 1 & 0 & 0 & 0 & 0 & 5 & 0 & 0 & 0 & 0 \\
\hline Zala & 22 & 0 & 0 & 0 & 0 & 0 & 0 & 0 & 1 & 0 & 0 \\
\hline Total & 3158 & 333 & 517 & 79 & 116 & 4 & 16 & 0 & 5 & 0 & 3 \\
\hline
\end{tabular}

*One mouflon and two unidentified species.

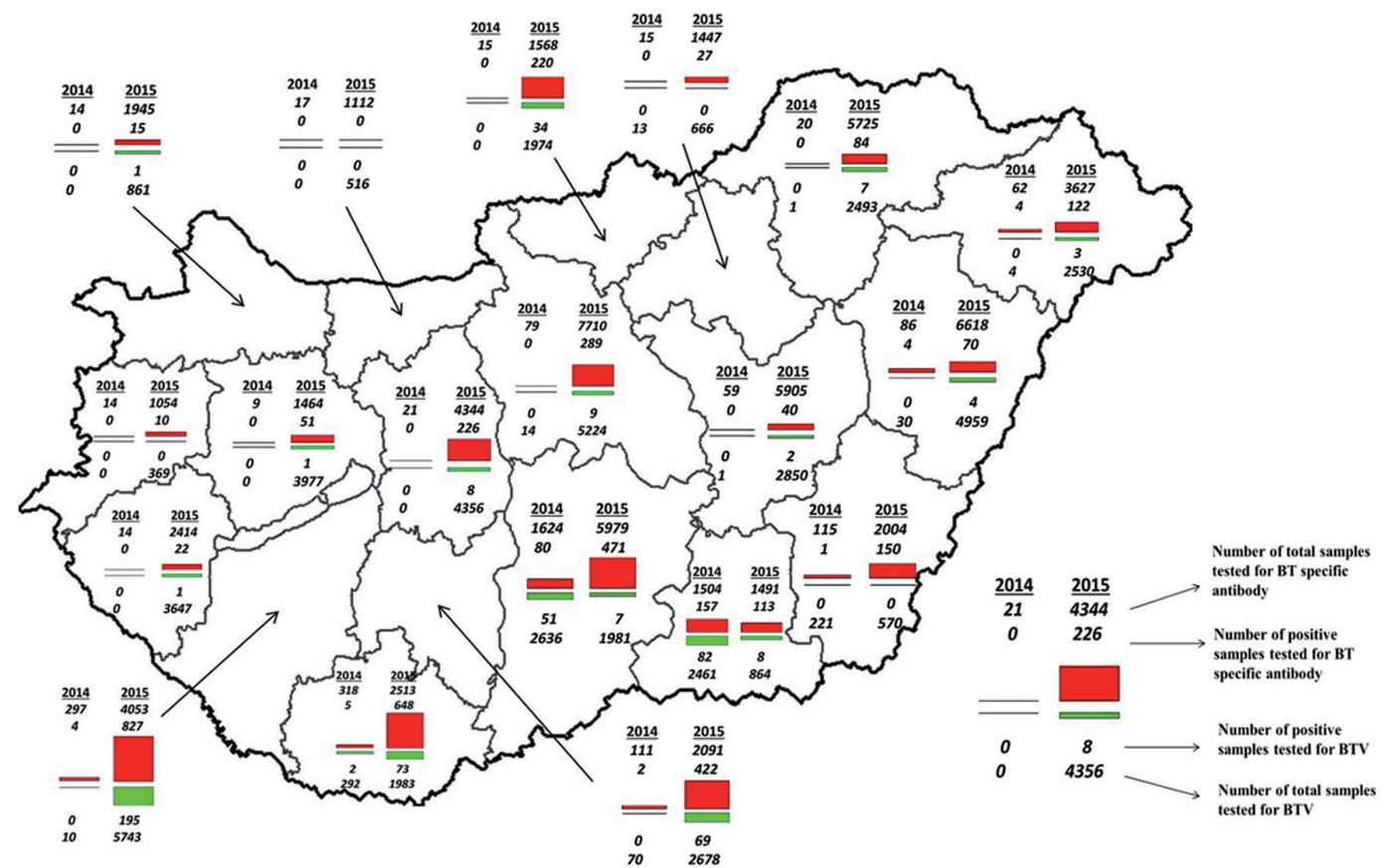

Fig. 1

Geographic distribution of BTV in 2014 and 2015, Hungary

The green and red rectangles represent the number of qPCR- and antibody ELISA-positive animals, respectively. The number of animals tested by both methods is also shown in each county. 


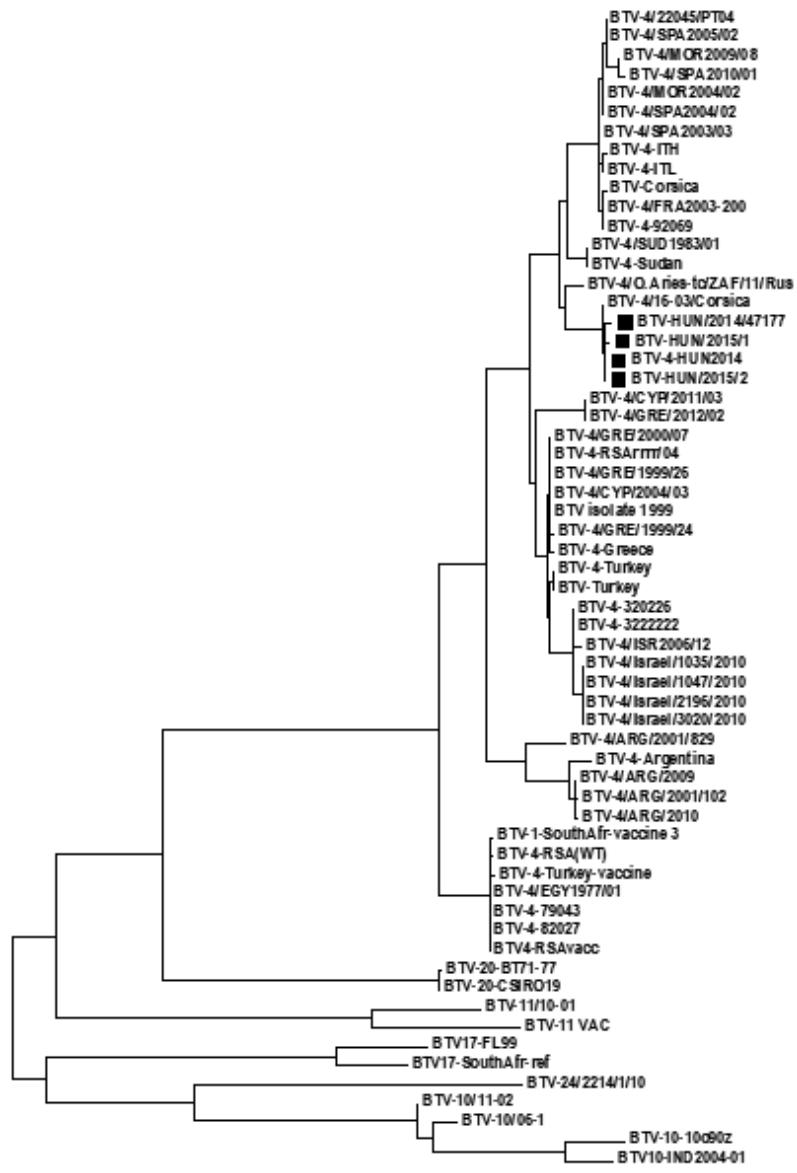

Fig. 2

Phylogenetic analysis of BTV strains using nucleotide sequences of Segment-2

Hungarian BTV strains are highlighted with black squares. The scale bar is proportional to the genetic distance. counties was related to outbreaks first reported in Tolna in September 2015 (http://www.oie.int/wahis 2/public/wahid. php/Diseaseinformation/WI). Additionally, viral RNA was detected in five biting midges (Culicoides sp.), each collected from a different county (Table 1 ).

During 2015, out of 63,146 samples tested for the presence of BTV-specific antibodies, 3807 (6\%) proved to be positive. In cattle, out of 57,250 samples, 3158 were seropositive (5.5\%). At least 10 seropositive cattle were detected in each county, except for Komárom-Esztergom, where no animals positive for BTV antibody were identified at all. Higher seropositivity rate was observed in sheep (517 positive out of 5120 samples; $10.1 \%$ ) and goat (116 positive out of 290 samples; $40 \%$ ), and positive samples originated mainly from Baranya (sheep, $\mathrm{n}=132$; goat, $\mathrm{n}=62$ ) and Somogy ( sheep, $\mathrm{n}=352$; goat, $\mathrm{n}=53$ ) counties. The prevalence of BTVspecific antibodies in buffalo was $5.6 \%$ (16 positive out of 284 samples) (Table 1 ).

In 2015, at least one BTV-4 outbreak was reported in almost every county, indicating the virus circulation among ruminants. In comparison with the data observed in 2014, fewer BTV-positive animals were identified in Bács-Kiskun county and Csongrád county. In addition, a relatively high number of BTV-positive animals was reported in Nógrád county. Moreover, simultaneously with the dissemination of BTV, the seroprevalence among livestock showed marked increase (Fig. 1).

Comparison of the nucleotide sequences of Segment- 2 of Hungarian BTV strains detected in 2015 and the reference BTV strains with sequence data available in the GenBank showed moderate-to-high sequence similarities and 100\% nt sequence identity with two earlier Hungarian isolates, BTV4HUN2014 and BTV-HUN/47177 (Fig. 2). Shotgun whole genome sequencing of a selected BTV-4 isolate determined
S1

2014

2015

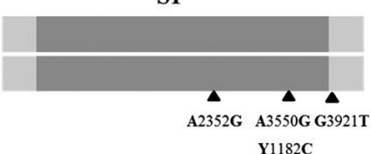

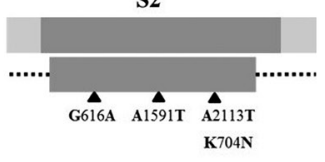

S3

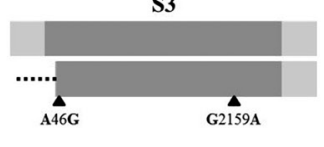

2014
2015

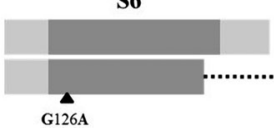

G126

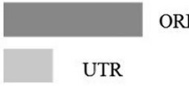

- Site of mutatio
S8

S7
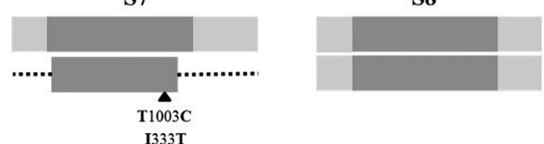

S9

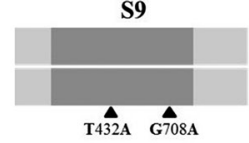

S4

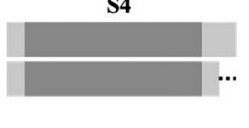

S5

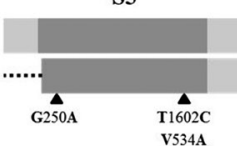

S10

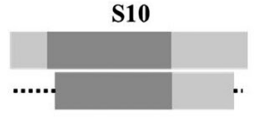

Fig. 3

Sequence variation between representative BTV strains isolated in 2014 and 2015 in Hungary

Black triangles represent the site of mutation in the open reading frame (ORF) and the untranslated region (UTR). Only mutations resulting in amino acid changes are indicated. 
the full-length coding region of genome segments S1, S4, S5 and $\mathrm{S} 8$, whereas partial genome sequences were determined for the remaining segments (S2, 94.9\%; S3, 99.1\%; S6, 99.1\%; S7, 95\%; S9, 99.1\%; S10, 99.3\%). We identified 14 mutation sites in this strain when compared to the BTV-4 strain detected in the previous year in Hungary. Thirteen nucleotide mutations were located in the coding regions, out of which four point mutations resulted in amino acid changes (Fig. 3). Overall, 18,624 nucleotides were determined, which represents $97.1 \%$ of the whole genome.

\section{Discussion}

In 2014 a novel, multireassortant BTV-4 emerged in Hungary causing BT epizootics, which coincided with a large outbreak in the Balkan Peninsula (Hornyák et al., 2015). Since the first occurrence of BT in the country, nucleic acid detection and serologic assays were carried out in order to monitor the spread of the disease and detect circulating virus strains. In September 2015, re-emergence of the disease was reported in Tolna and Somogy counties and the outbreak expanded to north, reaching Györ-Moson-Sopron county in November, the most distant county from Csongrád and BácsKiskun counties, where BT epizootics restricted in 2014. Genetic analysis of selected 2015 BTV isolates identified their high genetic relatedness to the BTV-4 strain reported from the 2014 outbreak in Hungary (Hornyák et al., 2015). This finding suggested that BTV-4 could have overwintered in infected competent vectors or a ruminant host. In addition, sequencing and phylogenetic analysis showed high genetic relatedness among Hungarian BTV-4 strains from 2014 and 2015 and those, which emerged in Corsica in November 2016 (Sailleau et al., 2017). All 10 genomic segments of the Hungarian BTV strain were closely related to the BTV-4 strain introduced to Corsica from Sardinia, a finding that is consistent with the theory that BTV-4 incursions to Europe are linked to outbreaks in North Africa (Sailleau et al., 2017).

Wild ungulates may play an important role in the transmission and maintenance of BTV (Ruiz-Fons et al., 2014; Niedbalski, 2015) and in this surveillance study we found a BTV-positive mouflon, providing evidence for the infection in wild mammals. Furthermore, we provided evidence for biting midges carrying the virus. As vaccination and movement restrictions can only be applied in farmed ruminants, it is essential to extend our knowledge on the relationship between wild ruminants and BTV in Hungary.

In conclusion, the detection of BTV genomic RNA in different geographic regions and the increased seroprevalence demonstrates that resurgence of the virus was likely associated with the overwintering of a multireassortant BTV-4 strain that emerged in 2014 in Hungary. Epidemiologic surveillance also provided evidence for vector competence of the local populations of biting midges as well as the potential role of wildlife reservoirs in disease maintenance. These findings along with adequate implementations of control measures and continued epidemiologic monitoring of ruminant population may help understanding the geographic dispersal of BT disease and the success of vaccination campaigns in Hungary.

Acknowledgment. The study was supported by the Momentum Program of the Hungarian Academy of Sciences. SM recieved Bolyai Scholarship during the study.

\section{References}

Bányai K, Borzák R, Ihász K, Fehér E, Dán Á, Jakab F, Papp T, Hetzel U, Marschang RE, Farkas SL (2014): Whole-genome sequencing of a green bush viper reovirus reveals a shared evolutionary history between reptilian and unusual mammalian orthoreoviruses. Arch. Virol. 159, 153-158. https://doi.org/10.1007/s00705-013-1796-2

Breard E, Sailleau C, Nomikou K, Hamblin C, Mertens PP, Mellor PS, El Harrak M, Zientara S (2007): Molecular epidemiology of bluetongue virus serotype 4 isolated in the Mediterranean Basin between 1979 and 2004. Virus Res. 125, 191-197. https://doi.org/10.1016/j. virusres.2007.01.002

Casaubon J, Chaignat V, Vogt HR, Michel AO, Thür B, RyserDegiorgis MP (2013): Survey of bluetongue virus infection in free-ranging wild ruminants in Switzerland. BMC Vet. Res. 9, 166. https://doi.org/10.1186/1746-6148-9-166 Durand B, Zanella G, Biteau-Coroller F, Locatelli C, Baurier F, Simon C, Le Dréan E, Delaval J, Prengère E, Beauté V, Guis H (2010): Anatomy of Bluetongue Virus Serotype 8 Epizootic Wave, France, 2007-2008. Emerg. Infect. Dis. 16, 1861-1868. https://doi.org/10.3201/eid1612.100412

Eschbaumer M, Wäckerlin R, Savini G, Zientara S, Sailleau C, Bréard E, Beer M, Hoffmann B (2011): Contamination in bluetongue virus challenge experiments. Vaccine 29, 4299-4301. https://doi.org/10.1016/j.vaccine.2011.04.049

Hofmann M, Griot C, Chaignat V, Perler L, Thür B (2008): Bluetongue Disease Reaches Switzerland. Schweiz Arch. Tierheilk. 150, 49-56. https://doi.org/10.1024/00367281.150.2.49

Hornyák Á, Malik P, Marton S, Dóró R, Cadar D, Bányai K (2015): Emergence of multireassortant bluetongue virus serotype 4 in Hungary. Infect. Genet. Evol. 33, 6-10. https://doi. org/10.1016/j.meegid.2015.03.036

Katsoulos PD, Giadinis ND, Chaintoutis SC, Dovas CI, Kiossis E, Tsousis G, Psychas V, Vlemmas I, Papadopoulos T, Papadopoulos O, Zientara S, Karatzias H, Boscos C (2016): Epidemiological characteristics and clinicopathological features of bluetongue in sheep and cattle, during the 2014 BTV serotype 4 incursion in Greece. Trop. Anim. Health Prod. 48, 469-477. https://doi.org/10.1007/ s11250-015-0974-5 
Lorusso A, Sghaier S, Carvelli A, Di Gennaro A, Leone A, Marini V, Pelini S, Marcacci M, Rocchigiani AM, Puggioni G, Savini G (2013): Bluetongue virus serotypes 1 and 4 in Sardinia during autumn 2012: new incursions or reinfection with old strains? Infect. Genet. Evol. 19, 81-87. https://doi. org/10.1016/i.meegid.2013.06.028

Maan S, Maan NS, Nomikou K, Batten C, Antony F, Belaganahalli MN, Samy AM, Reda AA, Al-Rashid SA, El Batel M, Oura CA, Mertens PP (2011): Novel bluetongue virus serotype from Kuwait. Emerg. Infect. Dis. 17, 886-889. https://doi. org/10.3201/eid1705.101742

Malik P, Balint A, Palfi V (2008): Bluetongue in Europe and Hungary. In Abstracts of the 'Akademiai beszamolok Virologia, bakteriologia, immunologia'. Budapest, 2009 Jan 26-29, p. 10 (in Hungarian).

Niedbalski W (2015): Bluetongue in Europe and the role of wildlife in the epidemiology of disease. Pol. J. Vet. Sci. 18, 455-461. https://doi.org/10.1515/pjvs-2015-0060

Orłowska A, Trębas P, Smreczak M, Marzec A, Żmudziński JF (2016): First detection of bluetongue virus serotype 14 in Poland. Arch. Virol. 161, 1969-1972. https://doi. org/10.1007/s00705-016-2857-0

Ruiz-Fons F, Sánchez-Matamoros A, Gortázar C, Sánchez-Vizcaíno JM (2014): The role of wildlife in bluetongue virus maintenance in Europe: lessons learned after the natural infection in Spain. Virus Res. 182, 50-58. https://doi. org/10.1016/j.virusres.2013.12.031

Saegerman C, Berkvens D, Mellor PS (2008): Bluetongue epidemiology in the European Union. Emerg. Infect. Dis. 14, 539-544. https://doi.org/10.3201/eid1404.071441
Sailleau C, Breard E, Viarouge C, Gorlier A, Quenault H, Hirchaud E, Touzain F, Blanchard Y, Vitour D, Zientara S (2018): Complete genome sequence of bluetongue virus serotype 4 that emerged on the French island of Corsica in December 2016. Transbound. Emerg. Dis. 65, e194-e197. https://doi.org/10.1111/tbed.12660

Savini G, Puggioni G, Meloni G, Marcacci M, Di Domenico M, Rocchigiani AM, Spedicato M, Oggiano A, Manunta D, Teodori L, Leone A, Portanti O, Cito F, Conte A, Orsini M, Cammà C, Calistri P, Giovannini A, Lorusso A (2017): Novel putative Bluetongue virus in healthy goats from Sardinia, Italy. Infect. Genet. Evol. 51, 108-117. https:// doi.org/10.1016/j.meegid.2017.03.021

Sun EC, Huang LP, Xu QY, Wang HX, Xue XM, Lu P, Li WJ, Liu W, $\mathrm{Bu} Z \mathrm{G}, \mathrm{Wu} \mathrm{DL}$ (2016): Emergence of a Novel Bluetongue Virus Serotype, China 2014. Transbound. Emerg. Dis. 63 , 585-589. https://doi.org/10.1111/tbed.12560

Vangeel I, De Leeuw I, Méroc E, Vandenbussche F, Riocreux F, Hooyberghs J, Raemaekers M, Houdart P, Van der Stede Y, De Clercq K (2012): Bluetongue sentinel surveillance program and cross-sectional serological survey in cattle in Belgium in 2010-2011. Prev. Vet. Med. 106, 235-243. https://doi.org/10.1016/j.prevetmed.2012.03.011

Zientara S, Sailleau C, Viarouge C, Hoper D, Beer M, Jenckel M, Hoffmann B, Romey A, Bakkali-Kassimi L, Fablet A, Vitour D, Breard E (2014): Novel bluetongue virus in goats, Corsica, France, 2014. Emerg. Infect. Dis. 20: 2123-2132. https://doi.org/10.3201/eid2012.140924 